\title{
Comparative Analysis of the Quality of Domestically Distributed Cut Phalaenopsis Flowers Based on the Season and Place of Origin
}

\author{
Hyun Kyung Kim and Ae Kyung Lee*
}

Citation: Kim, H.K.; Lee, A.K. Comparative Analysis of the Quality of Domestically Distributed Cut Phalaenopsis Flowers Based on the Season and Place of Origin. Horticulturae 2021, 7, 382. https://doi.org/10.3390/ horticulturae7100382

Academic Editor: Anastasios Darras

Received: 17 August 2021

Accepted: 29 September 2021

Published: 9 October 2021

Publisher's Note: MDPI stays neutral with regard to jurisdictional claims in published maps and institutional affiliations.

Copyright: (C) 2021 by the authors. Licensee MDPI, Basel, Switzerland. This article is an open access article distributed under the terms and conditions of the Creative Commons Attribution (CC BY) license (https:// creativecommons.org/licenses/by/ $4.0 /)$.
Department of Environmental Horticulture and Landscape Architecture, Environmental Horticulture Major, Dankook University, Cheonan 31116, Korea; hnkng97@naver.com

* Correspondence: akleekr@dankook.ac.kr; Tel.: +82-41-550-3646

\begin{abstract}
This study compared and analyzed the qualities of cut Phalaenopsis "V3" flowers based on the place of origin and season. An investigation of the senescence type showed that flowers originating from Korea had a higher rate of aging than those from China across all three seasons. Consequently, the vase life was also 3-5 days longer for Chinese flowers than those for Korean flowers, regardless of the season. Furthermore, the vase life was the longest in autumn, followed by spring and summer, with statistically significant differences. With respect to flower diameter, Chinese cut phalaenopsis flowers were relatively larger than the Korean ones on day 1 of the experiment. As the senescence process of wilting was initiated earlier in Korean flowers with a shorter vase life, they showed higher reductions in flower diameters as well. The fresh weight, water uptake, and water balance were lower for Korean flowers than those for Chinese flowers starting on day 5 of the experiment across all three seasons. Korean cut phalaenopsis flowers experienced difficulties in maintaining water levels following their water uptake on day 1 , which may have affected their vase life. Ethylene production showed a sharp increase on day 7 in Chinese cut flowers and day 5 in Korean cut flowers, with high amounts typically observed in spring, which coincided with the results of water loss. Hunter values $\mathrm{L}, \mathrm{a}$, and $\mathrm{b}$ and changes petal color $\Delta \mathrm{E}$ significantly differed not by place of origin but by season. Additionally, the sugar content of the solution inside the water tubes used when selling cut phalaenopsis flowers was investigated. Chinese flowers are subjected to pretreatment and posttreatment inside the water tube before being exported, while Korean flowers are treated with tap water. The Chinese flowers contained approximately seven times more sugar content compared to Korean flowers. This suggests that the treatment solution components, including sugar and other ingredients, of the Chinese cut flowers had a positive effect on water uptake and lowered the sensitivity to ethylene, which seemed to have an effect on the long vase life and quality. If Korean cut flowers are also distributed using a treatment agent, it is expected that the vase life will be improved and the satisfaction of consumers will be increased. However, since there are several possibilities that can affect post-harvest quality, it seems that additional experiments are needed. Moreover, as flower quality decreases in summer compared to those in spring or autumn, it will be necessary to reduce the differences in quality between seasons.
\end{abstract}

Keywords: cut flower; orchid; Phalaenopsis "V3"; senescence; sugar content; vase life

\section{Introduction}

Orchids are flowering plants of high importance in South Korea, with a cultivation area of 103 ha and a total sales worth of 44.8 billion KRW [1]. Among domestic orchids, phalaenopsis (Phalaenopsis spp.) accounts for approximately 33\% of the total cultivation area of orchids ( $34 \mathrm{ha}$ ) and approximately $44 \%$ of the annual sales production (19.6 billion KRW), thus constituting a critical element of the orchid industry [1]. In the past, phalaenopsis required high temperatures in winter, so the extraction period was concentrated from March to May due to problems such as heating costs and cultivation technology, but 
at present, advancements in cultivation technology through research on the treatment of growth regulators that promote flowering and environmental conditions related to temperature, humidity, and light have facilitated the export of phalaenopsis throughout the year [2]. Their diverse flower shapes and colors as well as long flowering periods have attracted increasing consumer interest, and the promotion of the import and export of potted and cut flowers of phalaenopsis has increased the global demand [3,4]. Until the mid-2000s, the sale of potted flowers was predominant, and that since 2010, following more active cultivation as well as the sale of cut flowers, the demand for cut flowers has steadily increased [2]. Regarding potted flowers, recent studies conducted in South Korea examined the quality of phalaenopsis, including factors such as irrigation time [5], treatment with growth regulators [5], and adaptation to $\mathrm{CO}_{2}$ conditions [6]. Regarding cut flowers, however, only one study investigated the use of vase life extenders and processing agents [7], suggesting a lack of studies on cut phalaenopsis flowers.

Cut flowers of phalaenopsis are mostly white in color, and as the use of white phalaenopsis flowers for weddings and funerals abroad increases, the interest in white phalaenopsis flowers has increased in the country [7]. White cut phalaenopsis flowers have been used for bouquets [8], and their proportion among cut flowers in flower jewelry sets used in ceremonies is the highest, indicating an increasing trend in the use of cut flowers [9]. As such, the demand for cut flowers of phalaenopsis has increased in South Korea; however, there is a shortage of growing farms. As a result, their import is high at 160,000 USD, but their export is merely 105 USD [10]. In the domestic market, both domestically grown and imported cut phalaenopsis flowers are sold at the same time, and according to [11], the most important factor of consumer decisions to purchase cut flowers was freshness of flowers, regardless of the country of origin. Thus, consumers prefer cut flowers of a high quality irrespective of their origin, but the quality differences between domestically grown and imported cut flowers have not yet been investigated. With respect to domestic cymbidium (Cymbidium spp.) flowers, growing farms have been continuously provided with information on cut flower quality so as to improve the quality of domestically grown flowers and to ultimately increase cut flower sales and exports [12]. Regarding phalaenopsis, likewise, to supplement the quality, quality information on imported and domestic cut flowers should first be analyzed to ensure the competitiveness of domestically grown cut flowers.

\section{Materials and Methods}

\subsection{Plant Materials}

The selected test materials were the Korean and the Chinese white Phalaenopsis "V3" cultivar, as based on the auction record at the Korea Agro-Fisheries and Food Trade Corporation (AT) flower joint market of flowers distributed at wholesale markets. Flowers were purchased in May, August, and October 2020, at the Flower Arcade at the Gangnam Express Bus Terminal, Gyeongbu-line. The flowers were cut to $60 \mathrm{~cm}$, and their qualities were analyzed. All Phalaenopsis "V3" are sold in a state of bloom, so the experiment was conducted at the stage when all flowers were in full bloom.

\subsection{Quality Evaluation}

The senescence type, vase life, flower diameter, relative fresh weight, water uptake, water balance, ratio of dry and fresh weight, ethylene production, sugar content of water tube solution, and flower color change of cut flowers of Phalaenopsis "V3" purchased at a wholesale market were recorded. To assess the senescence type, the lip browning, petal browning, lip wilting, petal wilting, peduncle necrosis, and peduncle breaking were analyzed according to the characteristics of the cut flowers. To record vase life, the flowers were categorized into Stage 1 for $20 \%$ senescence, Stage 2 for $50 \%$, and Stage 3 for $\geq 50 \%$, and the time at which two or more flowers in Stage 2 or 3 were observed was defined as the vase life. For the relative fresh weight, the calculation was based on the weight taken at day 1 of the experiment, and the water uptake was calculated by subtracting the weight 
on the previous day (container and solution). The water balance was calculated using the relative fresh weight and water uptake by subtracting the transpired amount from the uptake amount. The transpired amount was calculated by subtracting the weight of the previous day from the value of adding the fresh weight and water uptake. The ratio of dry and fresh weight was expressed as a percentage by dividing the dry weight by the fresh weight. To assess ethylene production, one cut flower was placed in a $500 \mathrm{~mL}$ conical flask within a sealed $12 \mathrm{~L}$ container for $4 \mathrm{~h}$, after which $1 \mathrm{~mL}$ gas was collected from the head space for analysis using a gas chromatograph (GC-2014, Shimadzu, Japan). The sugar content of the water tube solution for the water supply attached to the end of the stem of cut flower produced in autumn was measured using a digital refractometer (PAL-1, Atago, Japan). A chromameter (CR-400, Minolta, Japan) was used to examine the changes in flower color, for which the automatic calculations of the Hunter value L (lightness 100, darkness 0$)$, a (+ red, - green), and b (+ yellow, - blue) were used to estimate the total color difference value $(\triangle \mathrm{E})$ according to the following equation:

$$
\Delta \mathrm{E}=\left[(\Delta \mathrm{L})^{2}+(\Delta \mathrm{a})^{2}+(\Delta \mathrm{b})^{2}\right]^{1 / 2}
$$

$$
\begin{aligned}
& \Delta \mathrm{L}=\mathrm{Lt} \text { (at senescence) }-\mathrm{L} \text { (on day } 1 \text { of the experiment) } \\
& \Delta \mathrm{a}=\text { at (at senescence) }-\mathrm{a} \text { (on day } 1 \text { of the experiment) } \\
& \Delta \mathrm{b}=\mathrm{bt} \text { (at senescence) }-\mathrm{b} \text { (on day } 1 \text { of the experiment) }
\end{aligned}
$$

\subsection{Statistical Analyses}

The data were statistically analyzed through a $t$-test using SPSS program (SPSS 25.0 Statistics, SPSS Inc., Palo Alto, CA, USA).

\section{Results}

The result of examining the senescence type of the cut phalaenopsis flowers (Table 1) showed that, in Chinese cut flowers of phalaenopsis produced in spring, lip and petal wilting and peduncle breaking were mainly observed, and Korean cut flowers of phalaenopsis showed lip and petal wilting, petal browning, and peduncle breaking. In addition, Chinese cut phalaenopsis flowers produced in summer showed petal wilting and peduncle necrosis, whereas Korean cut phalaenopsis flowers produced in summer were similar to those produced in spring in terms of senescence type. Regarding flowers produced in autumn, Korean and Chinese flowers showed quality degradation due to petal wilting. Across all three seasons, the rate of senescence was slightly higher in Korean than in Chinese cut flowers. Based on this, the vase life was estimated, which was 3-5 days longer in Chinese than in Korean flowers, regardless of the season (Table 1). Among the flowers produced in spring, the vase life of Chinese flowers was 12.6 days and that of Korean flowers was 8.7 days; among the flowers produced in summer, it was 11.5 days in Chinese and 7.3 days in Korean flowers; and among the flowers produced in autumn, it was 14.2 days in Chinese and 8.9 days in Korean flowers; all differences were statistically significant. In the study of [13], the typical senescence type was reported to include upward folding, discoloration, and petal wilting, all of which may cause quality degradation and reduce vase life. Compared with Chinese flowers, domestic flowers showed all these symptoms, and their ornamental value was lowered, indicating that the vase life was significantly shorter in all three seasons. In addition, the vase life was the longest in the flowers produced in autumn, followed by those produced in spring and summer, among Korean and Chinese flowers, compared to the autumn, when the senescence type was less; the expression of senescence type in spring and summer was more diverse and higher. This is in line with previous reports of a shorter vase life in flowers produced in summer than those produced in other seasons [14,15], and there was a slight difference from the study of [16], where winter and autumn generally lowered the quality compared to spring and summer in several cut flower species including roses. According to a recent study, this seasonal difference is related to the stomatal regulation of water loss [17]. However, unlike cut flowers with leaves and stomata such as roses, the cut flower phalaenopsis is cut except for the leaves, 
so it is less affected by these effects, so the results may differ from previous studies. Vase life is an important factor of the quality of cut flowers, which depends on water uptake and transpiration [14], and [18] investigated consumer purchase behavior regarding cut flowers and found that, for all major cut flowers, the effect of vase life was crucial.

Table 1. Vase life and senescence type of cut Phalaenopsis "V3" flowers based on the place of origin and season.

\begin{tabular}{|c|c|c|c|c|c|c|c|c|}
\hline \multirow[b]{2}{*}{ Season } & \multirow[b]{2}{*}{ Country } & \multirow{2}{*}{$\begin{array}{c}\text { Vase Life } \\
\text { (Days) }\end{array}$} & \multicolumn{6}{|c|}{ Senescence Day (\%) } \\
\hline & & & $\begin{array}{c}\text { Lip } \\
\text { Browning }\end{array}$ & $\begin{array}{c}\text { Petal } \\
\text { Browning }\end{array}$ & $\begin{array}{c}\text { Lip } \\
\text { Wilting }\end{array}$ & $\begin{array}{c}\text { Petal } \\
\text { Wilting }\end{array}$ & $\begin{array}{l}\text { Peduncle } \\
\text { Necrosis }\end{array}$ & $\begin{array}{l}\text { Peduncle } \\
\text { Breaking }\end{array}$ \\
\hline \multirow{4}{*}{ Spring } & China & 12.6 & 0.0 & 23.3 & 53.3 & 50.0 & 23.3 & 43.3 \\
\hline & Korea & 8.7 & 0.0 & 76.7 & 86.7 & 93.3 & 0.0 & 73.3 \\
\hline & $t=$ & 7.554 & & & & & & \\
\hline & $p=$ & $0.000^{* * *}$ & & & & & & \\
\hline \multirow{4}{*}{ Summer } & China & 11.5 & 0.0 & 0.0 & 0.0 & 100.0 & 6.7 & 0.0 \\
\hline & Korea & 7.3 & 3.3 & 60.0 & 60.0 & 76.7 & 6.7 & 60.0 \\
\hline & $t=$ & 8.275 & & & & & & \\
\hline & $p=$ & $0.000^{* * *}$ & & & & & & \\
\hline \multirow{4}{*}{ Fall } & China & 14.2 & 0.0 & 0.0 & 0.0 & 100.0 & 0.0 & 0.0 \\
\hline & Korea & 8.9 & 0.0 & 3.3 & 0.0 & 100.0 & 0.0 & 0.0 \\
\hline & $t=$ & 23.644 & & & & & & \\
\hline & $p=$ & $0.000^{* * *}$ & & & & & & \\
\hline \multirow[t]{3}{*}{ Significant } & Season (A) & $* * *$ & & & & & & \\
\hline & Country (B) & $* * *$ & & & & & & \\
\hline & $\mathrm{A} \times \mathrm{B}$ & NS & & & & & & \\
\hline
\end{tabular}

NS and ${ }^{* * *}$ mean no significant and significant at $p \leq 0.001$, respectively.

Flower diameter was slightly larger in Chinese than in Korean flowers, based on the measurements made on day 1 of the experiment (Figure 1). Flower uniformity and size are essential factors for the purchase of cut flowers [19], and Chinese cut flowers with a slightly larger flower diameter are generally assumed to be preferred by consumers. In addition, the flower diameter on day 7 of the experiment when the senescence type was observed showed that, compared to Chinese cut flowers, Korean flowers exhibited a faster rate of senescence due to petal wilting, with a greater reduction in flower diameter. Phalaenopsis flowers are typically commercially distributed in full bloom, thus factors such as lip wilting after harvest probably lead to reduced flower diameters, so water content should be maintained to prevent quality degradation.

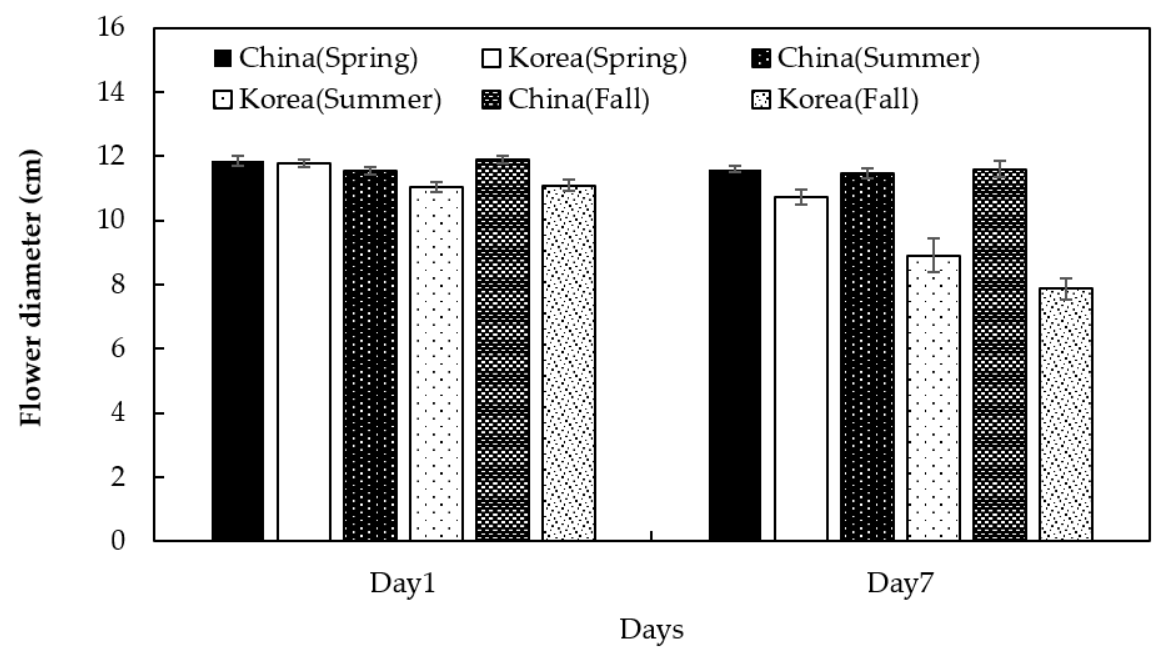

Figure 1. Flower diameter of cut Phalaenopsis "V3" flowers based on the place of origin and season on day 1 and day 7 of the experiment when the senescence type was observed. 
The relative fresh weight was lower in Korean cut flowers with a shorter vase life than in Chinese flowers on day 5 of the experiment, across all three seasons (Figure 2A), and the margin of decrease was the lowest in autumn when the vase life of the Korean and Chinese cut flowers was longer than during the other seasons. Based on this, the water uptake (Figure 2B) showed an increase on day 3 of the experiment, followed by a decrease on day 5, with lower levels across Korean flowers for all three seasons, as was the case with the relative fresh weight. Phalaenopsis is sold in bloom, but like Curcuma and Onisogalum, the leaves do not stick to the stem when cut, making it difficult to increase transpiration after harvest [20]. For this reason, it is judged that the water uptake increased at the beginning of the experiment, but deceased later on owing to insufficient water uptake. The water balance (Figure 2C) showed a decrease to below 0 from day 3 of the experiment, and the values were lower in Korean cut flowers, which showed the first signs of senescence earlier than the Chinese flowers, reaching the end of the vase life by day 9 of the experiment. This is presumed to be because the Korean flowers did not intake water as efficiently as in the first day compared to the Chinese flowers, affecting the vase life of the cut flower.

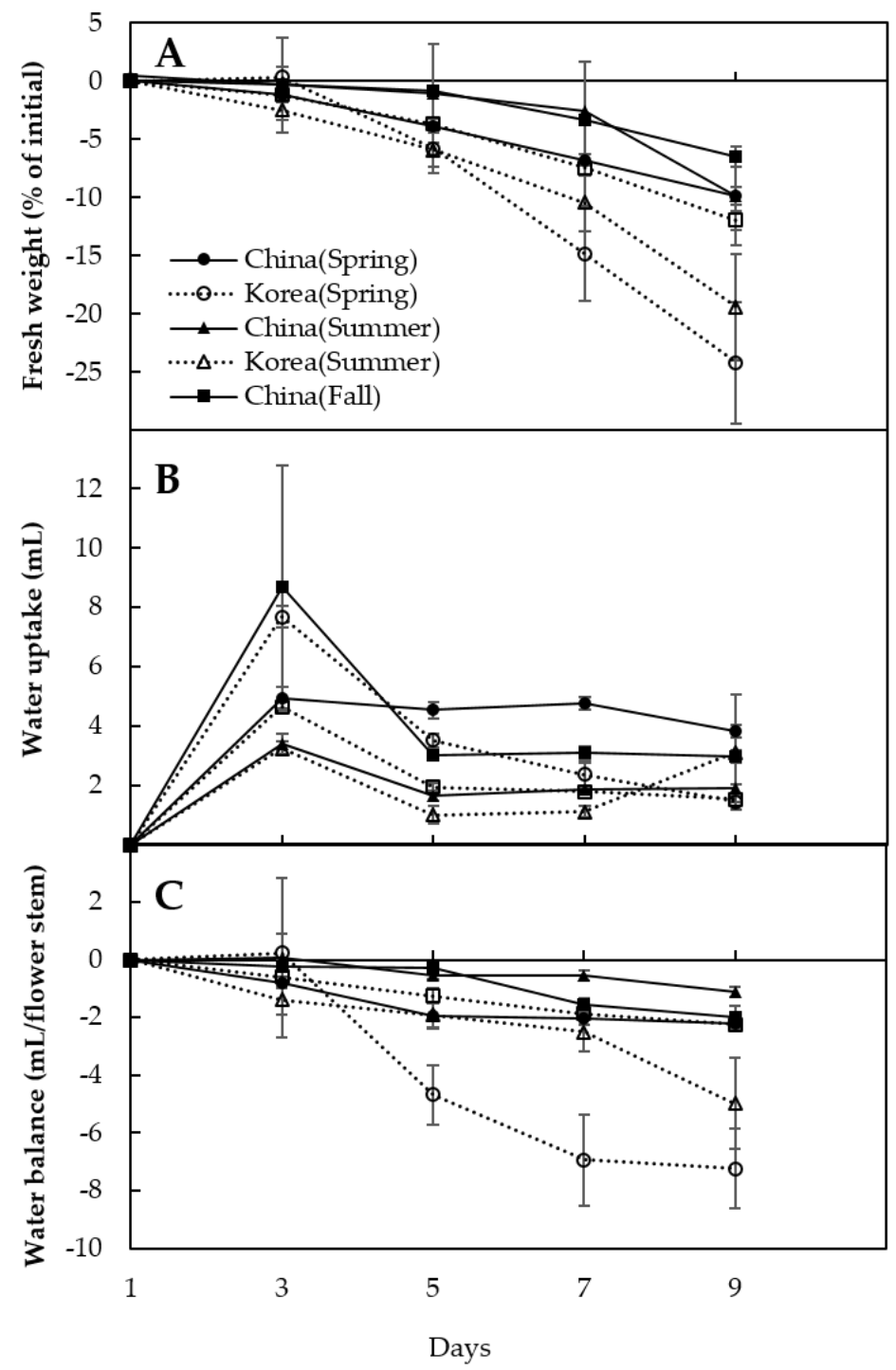

Figure 2. Changes of fresh weight (A), water uptake (B) and water balance (C) of cut Phalaenopsis "V3" flowers based on the place of origin and season. 
The ratio of dry and fresh weight of plants showed a higher value as the stress increased [21], and Korean flowers with a low moisture balance also showed a high ratio of dry and fresh weight in spring (Figure 3).

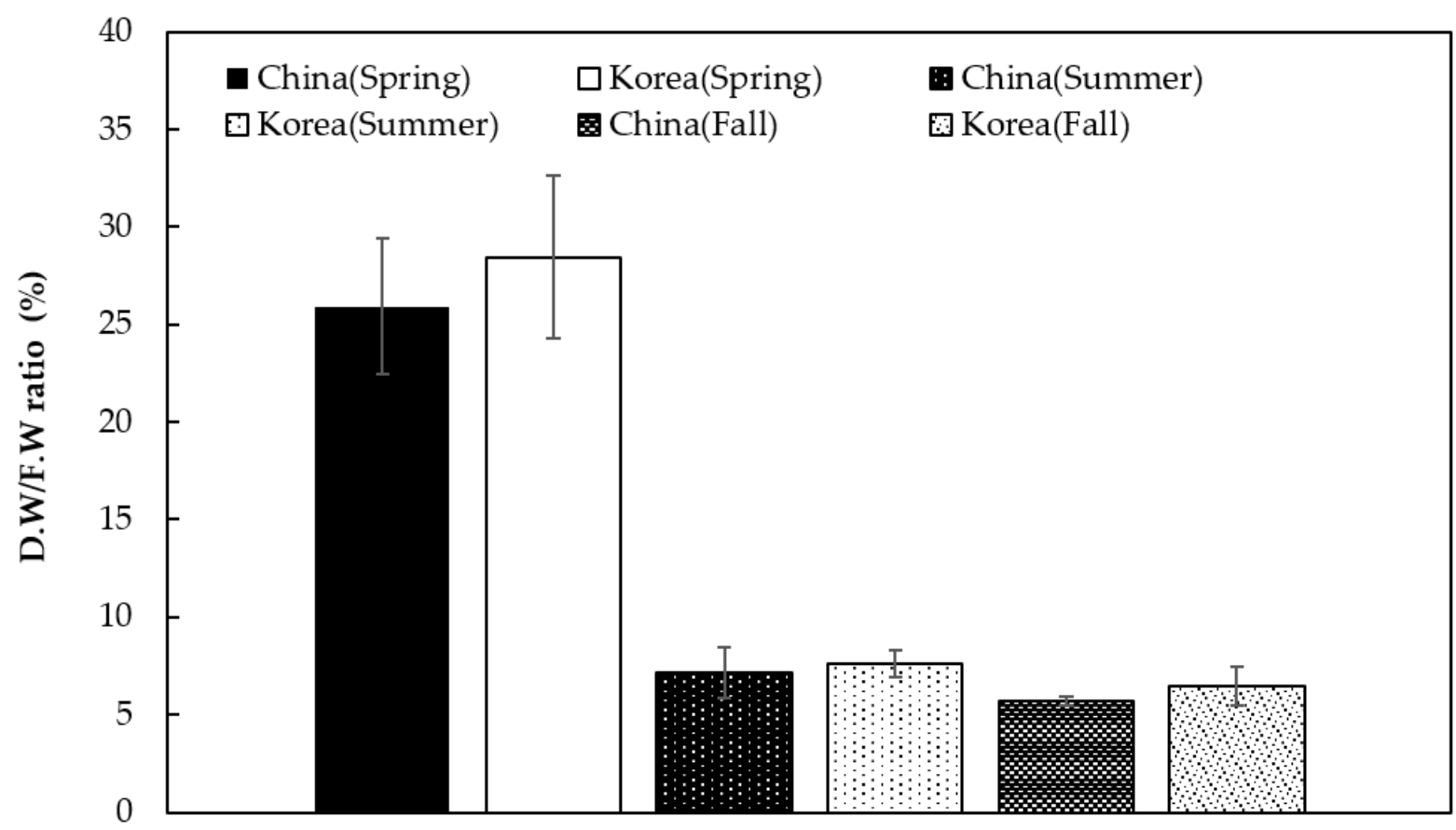

Day1

Figure 3. Changes of ratio of dry and fresh weight of cut Phalaenopsis "V3" flowers based on the place of origin and season.

Ethylene production (Figure 4) was markedly increased on day 7 of the experiment with the observation of the senescence type in Chinese cut flowers and on day 5 in Korean cut flowers produced in spring. As in the case of water balance, a slow decrease occurred in Chinese cut flowers until day 7 of the experiment, whereas Korean cut flowers showed a continuous decrease to "-" after day 3 of the experiment to reach a level approximately seven-fold lower than that of Chines flowers by day 9 of the experiment (Figure 2). With respect to seasonal effects, the production was slightly higher in spring, in line with the markedly reduced water content at this time of year. The authors of [22] reported a correlation of increased ethylene production and loss of moisture in phalaenopsis, which is in line with the results of the current study. In addition, Korean flowers produced more ethylene than Chinese flowers, as in the study of $[23,24]$, as orchids, including Phalaenopsis, are sensitive to ethylene, so they are considered to be affected by ethylene to have a short vase life. The authors of [25] used a 1-MCP agent to extend the vase life of cymbidium and reported the results of reduced ethylene production to implicate the need for a study to investigate the inhibition of ethylene production in phalaenopsis. 


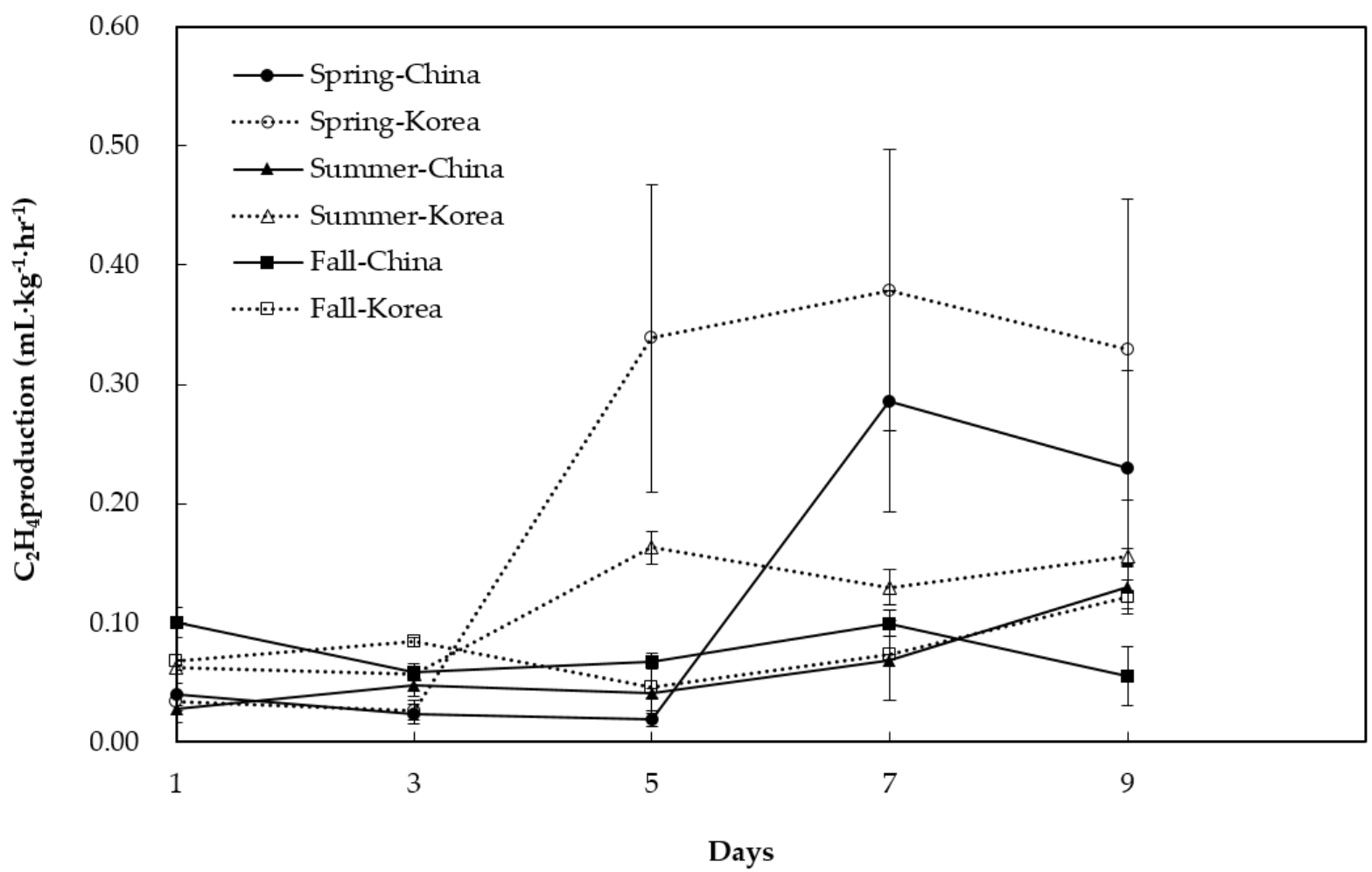

Figure 4. Changes in ethylene production of cut Phalaenopsis "V3" flowers based on the place of origin and season.

The flower color changed, based on the Hunter values $\mathrm{L}$, $\mathrm{a}$, and $\mathrm{b}$, on day 1 of the experiment and at senescence, the L value was high due to the white color of the "V3" cultivar (Table 2), with significant seasonal differences based on slightly higher L values in spring; however, no effect of the country of origin was observed. The L value on day 7 of the experiment was lower than that on day 1, except in autumn. The difference was particularly high in spring, which was in line with the results regarding the senescence type; wilting alone without browning led to senescence in autumn whereas browning occurred in spring (Table 1 ). The changes in $\mathrm{L}$, $\mathrm{a}$, and $\mathrm{b}$ values and chromaticity were found to vary significantly between seasons, rather than between countries of origin.

Table 2. Hunter value $\mathrm{L}, \mathrm{a}, \mathrm{b}$, and changes of petal color $\triangle \mathrm{E}$ of cut Phalaenopsis "V3" flowers based on the place of origin and season.

\begin{tabular}{|c|c|c|c|c|c|c|c|c|}
\hline \multirow{2}{*}{ Season } & \multirow{2}{*}{ Country } & \multicolumn{3}{|c|}{ Day 1} & \multicolumn{3}{|c|}{ Day 7} & \multirow{2}{*}{$\Delta \mathbf{E}^{\mathbf{y}}$} \\
\hline & & $\mathbf{L}^{\mathbf{z}}$ & $\mathbf{a}$ & $\mathbf{b}$ & $\mathbf{L}$ & $\mathbf{a}$ & $\mathbf{b}$ & \\
\hline \multirow{4}{*}{ Spring } & China & 96.3 & 0.7 & 2.6 & 84.4 & -0.3 & 1.8 & 11.9 \\
\hline & Korea & 94.9 & -1.4 & 2.2 & 86.8 & -0.3 & 2.9 & 8.3 \\
\hline & $t=$ & 1.906 & 5.977 & 2.406 & -1.342 & -0.449 & -3.022 & 1.840 \\
\hline & $p=$ & $0.065^{\mathrm{NS}}$ & $0.000^{* * *}$ & 0.230 * & $0.188^{\text {NS }}$ & $0.657^{\mathrm{NS}}$ & $0.008^{* *}$ & $0.075^{N S}$ \\
\hline \multirow{4}{*}{ Summer } & China & 90.2 & -0.3 & 1.6 & 86.2 & -0.3 & 1.5 & 5.7 \\
\hline & Korea & 89.0 & -0.3 & 2.2 & 86.3 & -0.5 & 2.8 & 5.6 \\
\hline & $t=$ & 0.781 & 0.564 & -3.728 & -0.069 & 3.275 & -4.650 & -0.256 \\
\hline & $p=$ & $0.440^{\mathrm{NS}}$ & $0.577^{N S}$ & $0.001^{* * *}$ & $0.945^{\mathrm{NS}}$ & $0.003^{* *}$ & $0.000^{* * *}$ & 0.799 NS \\
\hline \multirow{4}{*}{ Fall } & China & 88.5 & -0.5 & 1.6 & 89.8 & -0.7 & 2.7 & 5.9 \\
\hline & Korea & 88.2 & -0.3 & 1.6 & 88.1 & -0.4 & 2.1 & 5.5 \\
\hline & $t=$ & 0.150 & -7.817 & 0.494 & 1.146 & -6.353 & 4.740 & 0.287 \\
\hline & $p=$ & $0.881^{\mathrm{NS}}$ & $0.000^{* * *}$ & $0.625^{\mathrm{NS}}$ & $0.260 \mathrm{NS}$ & $0.000 * * *$ & $0.000^{* * *}$ & $0.776^{\mathrm{NS}}$ \\
\hline \multirow{3}{*}{ Significant } & Season $(\mathrm{A})$ & $* * *$ & $* * *$ & $* * *$ & * & $* * *$ & $* *$ & $* * *$ \\
\hline & Country (B) & NS & $* * *$ & NS & NS & NS & $* *$ & NS \\
\hline & $\mathrm{A} \times \mathrm{B}$ & NS & $* * *$ & $* * *$ & NS & $* *$ & $* *$ & NS \\
\hline
\end{tabular}

${ }^{\mathrm{z}} \mathrm{L}$, lightness $\left(100=\right.$ white, $0=$ black); a, redness $\left(-\right.$ green, + red); b, yellowness $(-$ blue,+ yellow $) .{ }^{\text {y }} \Delta \mathrm{E}=\left[(\Delta \mathrm{L})^{2}+(\Delta \mathrm{a})^{2}+(\Delta \mathrm{b})^{2}\right]^{1 / 2} \mathrm{NS}, *$,

$* *$, and ${ }^{* * *}$ means no significant and significant at $p \leq 0.05,0.01$ or 0.001 , respectively. 
The sugar content of the water tube used for the sale of cut phalaenopsis flowers was approximately $0.7^{\circ}$ Brix in the Chinese cut flowers and $0.1^{\circ}$ Brix in Korean flowers, with the former showing an approximately seven-fold higher sugar content (Figure 5). The sugar content of tap water was $0 \sim 0.1^{\circ}$ Brix - an inquiry to the seller revealed that Chinese cut phalaenopsis flowers were pretreated before exportation using a defined post treatment agent added to the water tube, while Korean cut flowers were treated with tap water only. Various treatment agents are used on cut flowers after harvest to increase vase life and maintain freshness, by which the flower quality is enhanced and senescence is delayed [26].

Among them, the sugar content can extend the vase life of cut flowers after harvest, and if the carbohydrate status is not sufficient, the physiological process after harvest changes and the flowers senescence faster [27]. Under these conditions, sugar can be added to supplement the required energy [27], and it affects the inhibition of the biosynthesis of ethylene or its sensitivity to it [28]. In the case of cut flower hydrangeas, there is a study that showed that the sugar component in the holding solution promotes transpiration rather than water uptake, thereby reducing the vase life of cut flowers [29]. On the other hand, in the case of Phalaenopsis, it seems that sugar components do not promote transpiration due to the absence of leaves, but rather play a role in facilitating water absorption. However, the sugar solution is also suitable for the growth of microorganisms, so a biocide must be additionally added to the solution [27]. In the study of [7], cut flowers of phalaenopsis were treated with the agent Professional Clear, which is reported to be effective in increasing the vase life in relation to the sugar content. The treatment solution containing sugar and other ingredients in the water tube of the Chinese cut flower phalaenopsis had a positive effect on water uptake and lowering of ethylene sensitivity, thus extending the vase life. Since the use of an appropriate treatment solution after harvesting cut flowers is one of the factors that determines the vase life [28], a similar method applied to Korean cut flowers of phalaenopsis, i.e., treatment solution to the water tube before distribution, can be assumed to extend vase life and increase customer satisfaction. Further research is needed in the future.

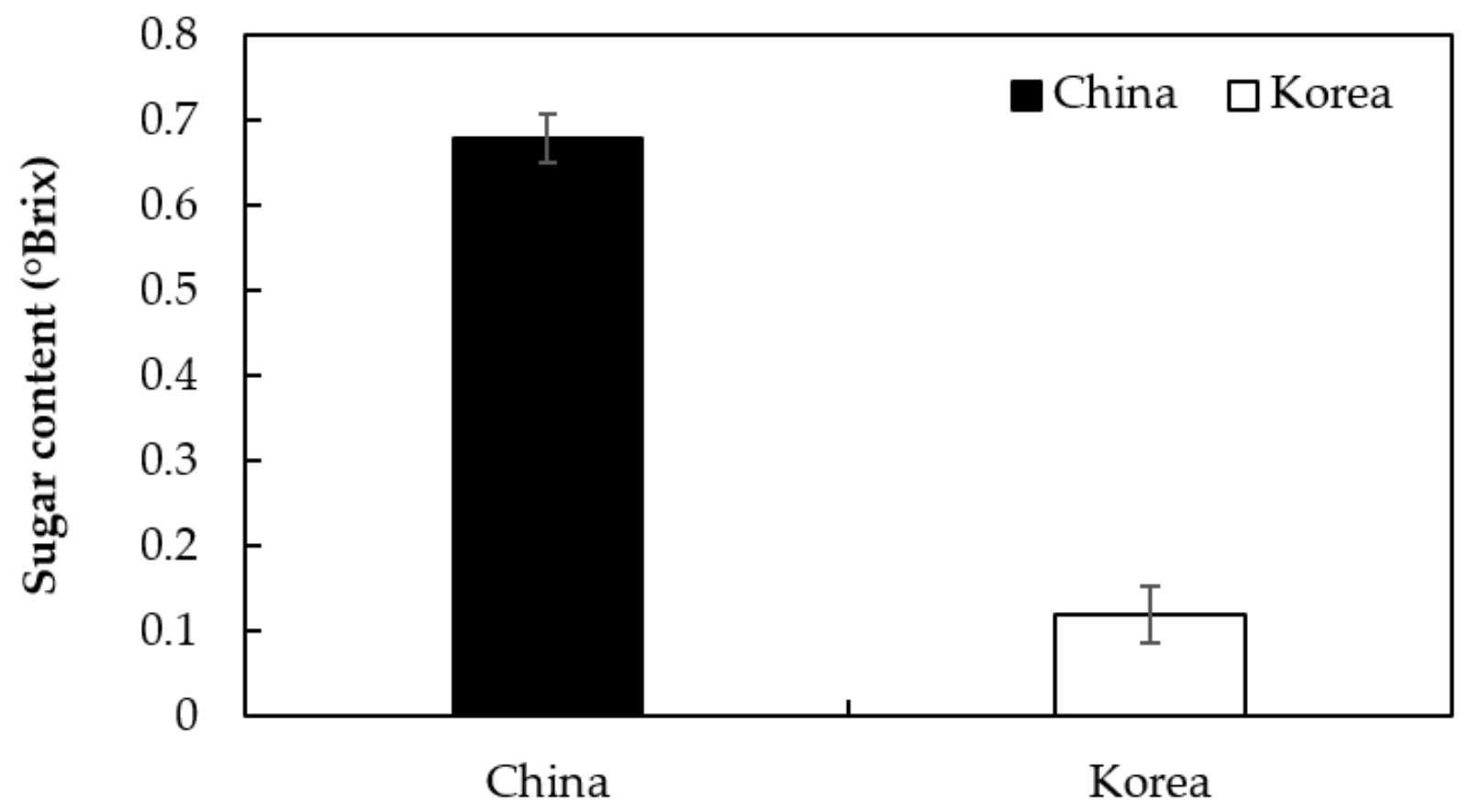

Figure 5. Sugar content of the water tube solution used for cut Phalaenopsis "V3" flowers in Fall based on the place of origin.

Therefore, even for an identical cultivar of Phalaenopsis "V3", Chinese cut flowers showed a higher quality in terms of a longer vase life, higher water uptake, and lower ethylene production than Korean flowers, regardless of the season. Notably, as differences were 
found due to the addition of a treatment agent to the water tube upon distribution, efforts in post-harvest quality management are predicted to convey a competitive advantage to the Korean cut phalaenopsis flowers through a more efficient water uptake and reduced ethylene production, so as to improve their quality. Furthermore, as the flower quality was lower in summer than in spring and autumn in both Korean and Chinese cut flowers, efforts should be made to reduce seasonal variation to ensure consistent quality.

Author Contributions: Conceptualization, H.K.K.; methodology, H.K.K.; software, H.K.K.; validation, H.K.K.; formal analysis, H.K.K. and A.K.L.; investigation, H.K.K.; writing and original draft preparation, H.K.K.; writing, review, and editing, A.K.L. and H.K.K.; supervision, A.K.L.; project administration, A.K.L.; funding acquisition, A.K.L. All authors have read and agreed to the published version of the manuscript.

Funding: This study was supported by the Korea Institute of Planning and Evaluation for Technology in Food, Agriculture, and Forestry (grant number IPET 120044022HD020).

Conflicts of Interest: The authors declare no conflict of interest.

\section{References}

1. Ministry of Africulture, Food and Rural Affairs. Flower Cultivation Status. Available online: https://www.mafra.go.kr/bbs/ mafra/71/324471/artclView.do (accessed on 1 April 2021).

2. Ye, B.W.; Lee, Y.R.; Kim, M.S.; Baek, K.Y.; Kim, D.H. Moth Orchid (Phalaenopsis); Korean Society for Horticulture Science: Wanju, Korea, 2013; pp. 308-311.

3. Runkle, E.; Wang, Y.T.; Blanchard, M.; Lopez, R. Growing the Best Phalaenopsis Part I: An Introduction to Potted Phalaenopsis Orchids; Culture Corner Orchids of Michigan State Univercity: East Lancing, MI, USA, 2007; pp. 24-28.

4. Jeong, J.H.; Jeon, J.B.; Kim, S.Y.; Oh, W. Effect of final irrigation timing before simulated dark shipping on post-shipping performance of potted Phalaenopsis Sogo Yukidian 'V3'. J. Bio-Environ. Control. 2021, 30, 65-71. [CrossRef]

5. Lee, H.B.; Kim, K.S. Growth and Inflorescence Initiation of Phalaenopsis orchids by paclobutrazol treatment. Flower Res. J. 2020, 28, 250-258. [CrossRef]

6. Lim, N.H.; Lee, H.B.; An, S.K.; Kim, K.S. Acclimation of young Doritaenopsis Queen Beer 'Mantefon' plantsunder increased CO2 concentration. Flower Res. J. 2018, 26, 11-18. [CrossRef]

7. Lee, Y.R.; Lee, D.S.; Jeong, S.J. Changes in the quality of cut Phalaenopsis flower as affected by Hwajoung, AVB and Professional Clear. J. Korean Soc. People Plants Environ. 2013, 16, 133-136. [CrossRef]

8. Kim, E.Y.; Yu, J.H. Trend analysis of celebrity wedding bouquet to its component. J. Korean Soc. Costum. 2018, 68, 19-37. [CrossRef]

9. Kim, Y.H.; Kim, M.J.; Yoon, S.Y.; Choi, B.J. A study on the analysis of the trends and expression techniques of flower jewelry. Korean Soc. Floral Art Design 2020, 43, 124-138.

10. Korea Agricultural Trade Information. Import and Export Statistics System. Available online: https:/ /www.kati.net/statistics/ periodPerformance.do (accessed on 1 April 2021).

11. Park, G.W.; Choi, I.C.; Seo, H.S.; Kim, C.H. A Study on the Consumption Patterns of Flowers in Korea and Japan; Korea Rural Economic Institute, Korea Rural Economic Institute: Naju, Korea, 2020; pp. 1-137.

12. Rural Development Administration. Orchid Industry and Export Status. Available online: https://www.rda.go.kr:2360/board/ board.do?mode=view\&prgId=day_farmprmninfoEntry\&dataNo=100000742966 (accessed on 1 June 2021).

13. Porat, R.; Borochov, A.; Halevy, A.H.; O'Neill, S.D. Pollination-induced senescence of Phalaenopsis petals. Plant Grow. Regul. 1994, 15, 129-136. [CrossRef]

14. Lee, J.H.; Yoon, J.W.; Oh, S.I.; Lee, A.K. Relationship between cultivation environment and postharvest quality of cut rose 'Lovely Lydia'. Korean J. Hort. Sci. Technol. 2019, 38, 263-270. [CrossRef]

15. Kim, H.K.; Oh, S.I.; Lee, A.K. Quality of cut spray roses grown in a seasonal cultivation environment of a smart farm in Honam, Korea. Flower Res. J. 2020, 28, 285-293. [CrossRef]

16. Fanourakis, D.; Velez-Ramirez, A.I.; In, B.C.; Barendse, H.; van Meeteren, U.; Woltering, E.J. A survey of preharvest conditions affecting the regulation of water loss during vase life. Acta Hortic 2015, 1064, 195-204. [CrossRef]

17. Fanourakis, D.; Hyldgaard, B.; Giday, H.; Aulik, I.; Bouranis, D.; Körne, O.; Ottosen, C.O. Stomatal anatomy and closing ability is affected by supplementary light intensity in rose (Rosa hybrida L.). Hort. Sci. 2019, 46, 81-89. [CrossRef]

18. Lim, J.H.; Shim, M.S.; Seo, J.Y.; Baek, Y.H. Conjoint analysis of the Korean floriculture market for the main cut flowers to predict the demand for floriculture plants. Korean J. Hort. Sci. Technol. 2014, 32, 721-729. [CrossRef]

19. Jeong, E.; Noh, S.W.; An, J.H.; Han, T.H. A measurement of longevity and preference test of cut Alstroemeria new cultivar. Agric. Sci. Technol. Res. 2014, 49, 45-53. [CrossRef]

20. Hwang, S.A.; Kim, Y.A. Harvesting stage, exogenous ethylene, and water dipping time after harvest on quality of cut Curcuma (Curcuma alismatifolia) flowers. Flower Res. J. 2014, 22, 140-148. [CrossRef] 
21. Lee, Y.K.; Cho, I.H.S.; Jeon, M.S.; Kim, L.H. Dry matter and nutrients contents in plant bodies of LID and roadside. J. Wetlands Res. 2021, 23, 35-43. [CrossRef]

22. Sun, Y.; Christensen, B.; Liu, F.; Wang, H.; Mu“ller, R. Effects of ethylene and 1-MCP (1-methylcyclopropene) on budand flower drop in mini Phalaenopsis cultivars. Plant Grow. Regul. 2009, 59, 83-91. [CrossRef]

23. Huang, Y.W.; Tsai, Y.J.; Cheng, T.C.; Chen, J.J.; Chen, F.C. Physical wounding and ethylene stimulated embryogenic stem cell proliferation and plantlet regeneration in protocorm-like bodies of Phalaenopsis orchids. Genet. Mol. Res. 2014, 13, $9543-9557$. [CrossRef]

24. Porat, R.; Halevy, A.H. An increase in ethylene sensitivity following pollination is the initial event triggering an increase in ethylene production and enhanced senescence of Phalaenopsis orchid flowers. Physiol. Plant. 1995, 93, 778-784. [CrossRef]

25. Heyes, J.A.; Johnston, J.W. 1-methylcyclopropene extends Cymbidium orchid vaselife and prevents damaged pollinia from accelerating sesescence. New Zealand J. Crop. Hort. Sci. 1988, 26, 319-324. [CrossRef]

26. Choi, M.P.; Lee, P.O.; Kim, W.H. Effect of pretreatments on optimal harvesting stage and harvesting stages of cut roses bred in Korea. Korean J. Hort. Sci. Technol. 2013, 31, 573-579. [CrossRef]

27. Kaviani, B.; Sharafshah Rostami, A. Effect of glucose, fructose, and sucrose on vase life, antioxidants enzymes, and some physiologic parameters of carnation cv. 'Yellow Candy' cut flower. J. Hort. Sci. 2021. [CrossRef]

28. Ajish, M.; Sha, K.; Kumar, S.; Karthikeyan, P.K.; Praveen Sampath Kumar, C.; Joshi, J.L. Role of preservative chemicals on extending vase life along with quality attributes of Gerbera cut flowers. Plant Arch. 2020, 20, 4762-4764.

29. Ku, B.S.; Cho, M.S. Vase life and quality as affected by various holding solution of cut Hydrangea macrophylla. Flower Res. J. 2014, 22, 12-20. [CrossRef] 